\title{
Analisis Penetapan Harga Jual pada Pembiayaan Murabahah berdasarkan Perspektif Islam di Koperasi Simpan Pinjam dan Pembiayaan Syariah (KSPPS) BMT AL-Falah Sumber
}

\author{
Diana Djuwita, Dian Purnamasari \\ Program Studi Perbankan Syariah, FSEI IAIN Syekh Nurjati, Cirebon \\ email: dianadjuwita12@gmail.com
}

\begin{abstract}
Abstrak
BMT Al-Falah merupakan Lembaga Jasa Keuangan Mikro Syariah yang berbadan hukum koperasi. Salah satu kegiatan BMT Al-Falah adalah menyalurkan dana dalam bentuk pembiayaan yang berbasis bai' atau jual beli dengan akad murabahah, yang mana merupakan salah satu produk pembiayaan yang paling banyak digunakan oleh BMT, karena akadnya sederhana serta adanya keuntungan yang didapatkan BMT berupa margin. Margin keuntungan didapatkan atas dasar kesepakatan antara kedua pihak dengan prinsip keadilan, saling ridho dan tidak ada unsur paksaan. Penelitian ini bertujuan untuk mendeskripsikan praktik murabahah dan perhitungan penentuan harga jual pada pembiayaan murabahah di BMT Al-Falah Sumber.

Metode penelitian yang digunakan adalah metode penelitian lapangan (field research). Penulis menjelaskan secara terperinci tentang penetapan harga jual pada pembiayaan murabahah berdasarkan perspektif Islam di BMT Al-Falah Sumber. Data yang disajikan berupa data primer dan sekunder, teknik pengumpulan data menggunakan teknik dokumentasi untuk mengambil bukti dilaksanakannya data yang berkaitan dengan BMT Al-Falah Sumber dengan cara pengamatan langsung serta melakukan wawancara dengan informan. Selanjutnya dilakukan analisis dengan metode analisis deskriptif kualitatif.

Berdasarkan hasil penelitian, penetapan harga jual murabahah di BMT Al-Falah Sumber menggunakan fixed rate dengan metode flat rate, yang mana penetapan margin dan hutang pokok yang dibebankan setiap bulan adalah sama sehingga pembayaran total cicilan setiap bulan besarnya tetap. Ditinjau dari hukum Islam, diperbolehkan bagi siapapun untuk mencari keuntungan tanpa ada batasan keuntungan tertentu selama mematuhi hukum-hukum Islam, serta menentukan standar harga sesuai dengan kondisi pasar yang sehat. Namun bila terjadi penyimpangan dan kesewenang-wenangan harga dengan merugikan pihak konsumen, maka tidak diperbolehkan. Menurut analisa peneliti di BMT Al-Falah dalam penetapan harga jual sudah cukup baik dan sesuai dengan tuntunan syariah, karena mengacu pada Fatwa DSN No. 04/DSN-MUI/IV/2000 dan juga ditetapakan dengan mempertimbangkan prinsip-prinsip penetapan harga jual yang sesuai pandangan Islam yaitu prinsip suka sama suka, saling ridha, prinsip kejujuran, dan prinsip keadilan.
\end{abstract}

Kata kunci: Baitul Maal wat-Tamwil, Murabahah, Penetapan Harga Jual, Perspektif Islam 


\begin{abstract}
BMT Al-Falah is Micro Sharia Finance Entity which has legal formal as koperasi. One kind of activity in BMT Al-Falah is distributing fund as finance whichis called bai' with murabahah contract, which is one kind of product that dominant used in BMT because it has simple contract and there is profit which is taken by BMT as margin. Profit margin is taken by agreement between both of member and BMT with justice principle, mutual assent, and no compulsion.the aim of this research areto describe the practice of Murabahah and to determinate selling price of murabahah finance in BMT Al-Falah Sumber.

Research methode which is used in this research is field research. Researchers make in detail about the sale price determination on murabahah financing based on Islamic perspective in BMT Al-Falah Sumber. The data presented in the form of primary and secondary data, data collection techniques using documentation techniques to retrieve evidence of the implementation of data related to BMT Al-Falah Source by way of direct observation and conduct interviews with informants. Furthermore, the analysis was done by qualitative descriptive analysis method.

Based on the result of research, determining the selling price of murabahah in BMT Al-Falah Source using fixed rate with flat rate method, where the determination of margin and principal debt charged each month is the same so that the total repayment of monthly installment is fixed. Judging from Islamic law, it is permissible for anyone to seek profit without any limitation of certain advantages as long as comply with Islamic laws, as well as setting price standards according to healthy market conditions. However, if there is deviation and arbitrariness of the price by harming the consumer, it is not allowed. According to the analysis of researchers at BMT Al-Falah in determining the selling price is quite good and in accordance with the guidance of sharia, because it refers to the Fatwa DSN. 04 / DSN-MUI / IV / 2000 and also set by considering the principles of price fixing according to Islamic view of the principle of likes like, mutual pleasure, honesty principle, and the principle of justice.
\end{abstract}

Kata kunci: Baitul Maal wat-Tamwil, Murabahah, The Determination of Selling Price, Islamic Perspective 


\section{PENDAHULUAN}

\section{Latar Belakang}

Kinerja lembaga keuangan mikro syariah, Baitul Maal WatTamwil (BMT), yang beroperasi atas dasar sistem syariah dimaksudkan untuk menggambarkan kemampuan BMT dalam manjalankan perannya sebagai lembaga intermediasi yang menyentuh lapisan masyarakat miskin yang tidak di sentuh oleh lembaga keungan bank, yang selama ini lebih berpihak kepada orang kaya daripada orang miskin. ${ }^{1}$

Pengaturan BMT mengacu pada berbagai peraturan antara lain UU Nomor 25 Tahun 1992 tentang Koperasi beserta Peraturan Pelaksanaannya, SK Menteri Negara Koperasi dan UKM. ${ }^{2}$.

Seperti halnya bank syariah, kegiatan BMT adalah melakukan penghimpunan dana (prinsip wadhiah dan mudharabah) dan penyaluran dana (prinsip bagi hasil, jual beli dan ijarah) kepada masyarakat. ${ }^{3}$ Salah satu produk pembiayaan yang ditawarkan oleh BMT adalah pembiayaan dengan akad murabahah. Secara bahasa, murabahah bermakna tumbuh dan berkembang dalam perniagaan. ${ }^{4}$ Akad murabahah adalah jual beli barang pada harga asal dengan tambahan keuntungan yang disepakati antara pihak bank dan

${ }^{1}$ Muhammad. Lembaga Keuangan Mikro Syariah. (Yogyakarta:Graha Ilmu, 2009) hal 84

${ }^{2}$ EuisAmalia,Keadialan Distributif dalam Ekonomi Islam Penguatan Peran LKM dan UKM di Indonesia,(Jakarta:Rajawai,2009), 242.

${ }^{3}$ Kusmiyati, Asmi Nur Siwi. Risiko Akad dalam Pembiayaan Murabahah pada BMT di Yogyakarta (dari Teori ke Terapan) (Yogyakarta: La Riba, 2007), 28.

${ }^{4}$ Ismail Nawawi, Fikih Muamalah Klasik dan Kontemporer, (Bogor: Penerbit Ghalia Indonesia, 2012), 91. nasabah. Pada akad murabahah penjual menyebutkan harga pembelian barang kepada pembeli kemudian ia mensyaratkan atas laba dalam jumlah tertentu. ${ }^{5}$

Dalam penentuan harga jual murabahah terdapat mark-up/margin. Harga jual bank yang disepakati adalah harga beli dari pemasok ditambah mark-up dan biaya-biaya yang timbul dari proses pembelian barang tersebut oleh bank. Bukan saja harga beli bank dari pemasok (cost price) yang harus diungkapkan oleh bank kepada nasabah dan disepakati bersama di awal sebelum penandatanganan akad murabahah, tetapi juga markup/margin harus disepakati di awal sebelum kedua belah pihak menandatangani akad murabahah. ${ }^{6}$

$$
\text { Mark-up/margin dapat }
$$

ditentukan baik dalam bentuk lumpsum atau dengan menetapkan rasio tertentu terhadap harga beli bank. Markup/margin tersebut hanya boleh ditetapkan satu kali untuk satu kali transaksi pembelian barang oleh nasabah. Artinya, tidak diperkenankan untuk ditetapkan bahwa nasabah membayar mark-up/margin tersebut setiap jangka waktu tertentu, misalnya untuk setiap bulan. Apabila diperjanjikan demikian, maka markup/margin tidak ubahnya dengan bunga bank yang haram hukumnya menurut ketentuan syariah. ${ }^{7}$ Berdasarkan latar belakang masalah yang telah diuraikan, maka tujuan penelitian ini adalah untuk (1) Mengetahui mekanisme penetapan harga jual pembiayaan murabahah di

\footnotetext{
${ }^{5}$ Heri Sudarsono, Bank dan Lembaga Keuangan Syariah, cet ke-2 (Yogyakarta: Ekonesia, 2004), 62.

${ }^{6}$ Sutan,Remi Sjahdeini. Perbankan Syariah, Produk-produk dan aspek-aspek hukumnya...,212.

${ }^{7}$ Sutan,Remi Sjahdeini. Perbankan Syariah, Produk-produk dan aspek-aspek hukumnya...,212.
} 
BMT AL-Falah, (2) Mengetahui penetapan harga jual pembiayaan murabahah di BMT AL-Falah, dan (3) Mengetahui kesesuaian penetapan harga jual pembiayaan murabahah di BMT Al-Falah dengan Perspektif Islam.

\section{Metode Penelitian}

Jenis penelitian ini adalah penelitian lapangan menggunakan pendekatan penelitian kualitatif. Sumber data dari penelitian ini adalah data primer dan sekunder. Sumber data primer dalam penelitian ini diperoleh dari wawancara langsung kepada pihak-pihak yang bersangkutan yaitu dengan manajer, marketing, admin pembiayaan dan nasabah. Sedangkan data sekunder dalam penelitian ini diperoleh dengan studi dokumentasi. Teknik pengumpulan data yang digunakan dalam penelitian ini adalah wawancara, studi dokumentasi, studi pustaka, dan observasi. Teknik analisis data meliputi reduksi data, display data, dan penarikan kesimpulan serta verifikasi data.

Teknik keabsahan data yang digunakan yaitu triangulasi data, dimana peneliti menguji keabsahan data dengan membandingkan data yang diperoleh dari beberapa sumber tentang data yang sama, seperti dari marketing, manajer, dan seterusnya tentang data pembiayaan murabahah.

\section{PEMBAHASAN}

\section{Mekanisme Penetapan Harga Jual Pembiayaan Murabahah di BMT AL-Falah Sumber}

Metode penentuan harga jual murabahah yang dilakukan oleh BMT AL-Falah adalah menggunakan metode keuntungan flat dimana perhitungan marjin keuntungan terhadap nilai harga pokok pembiayaan tetap dari satu periode ke periode lainnya, walaupun baki debetnya menurun sebagai akibat dari adanya angsuran harga pokok. Mekanisme penentuan harga jual pembiayaan murabahah di BMT ALFalah dilakukan dengan prinsip saling ridho (antaroddin), prinsip keadilan, adanya proses negosiasi (tawarmenawar) antara pihak BMT dan anggota serta kesepakatan antara kedua belah pihak tanpa adanya unsur paksaan $\left(\right.$ ikroh) ${ }^{8}$

Penentuan harga jual dapat dilihat dari beberapa pertimbangan seperti jangka waktu (tenor), penggunaan dana dan kondisi anggotanya, sehingga pihak BMT memberi kelonggaran dalam mengangsur yaitu mempertimbangkan kemampuan anggota untuk mengangsur setiap bulan kemudian dari pihak BMT akan melakukan kesepakatan antara anggota dangan BMT. Setelah mendapatkan beberapa jawaban terkait dengan metode yang digunakan oleh BMT ALFalah, pihak BMT yang diwakili oleh marketing akan melakukan survey. Selain itu juga BMT akan menerima komoditas atau aset lain sebagai jaminan atas risiko kredit atau terjadinya kegagalan anggota dalam membayar angsuran. ${ }^{9}$ Adapun prinsipprinsip penilaian untuk kelakayakan anggota mendapatkan pembiayaan murabahah di BMT AL-Falah Sumber dilakukan dengan analisis 5C, yaitu character , capacity, capital , condition, collateral.

${ }^{8}$ Hasil Wawancara dengan Pak Azhar selaku Manager Cabang Sumber terkait mekanisme penetapan harga jual pembiayaan murabahah di BMT AL-Falah, pada hari Selasa tanggal 14 Februari 2017, pukul 10.30.

${ }^{9}$ Hasil Wawancara dengan Pak Azhar selaku Manager Cabang Sumber terkait mekanisme penetapan harga jual pembiayaan murabahah di BMT AL-Falah, pada hari Selasa tanggal 14 Februari 2017, pukul 10.00. 
BMT AL-Falah hanya menerapkan tiga prinsip untuk menganalisa kelayakan pemberian pembiayaan murabahah bagi calon anggota yaitu character, collateral (jaminan), dan capacity (kapasitas). Character biasanya yang dianalisa adalah riwayat pembiayaan sebelumnya, informasi dari lingkungan sekitar, informasi pendapatan usaha, kesanggupan membayar angsuran tiap bulan dan BI checking. Penggunaan BI checking untuk mengetahui calon anggota yang mengajukan pembiayaan memiliki kewajiban pada bank lain, dan biasanya analisis BI Checking hanya dikhususkan untuk pembiayaan skala makro, sedangkan untuk pembiayaan mikro BMT AL-falah tidak menganalisa dengan BI checking. Untuk analisis jaminan biasanya BMT AL-Falah melihat beberapa aspek, yaitu kualitas barang, harga barang di pasar, modal calon anggota yang dimiliki sekarang dan dilihat juga dari usaha-usaha yang calon anggota miliki. Untuk Jenis-jenis barang yang dapt dijadikan jaminan seperti, tanah, bangunan, motor, mobil, BPKB, dan lain-lain. Kemudian analisis capacity (kapasitas) yaitu tingkat kemampuan calon anggota untuk mengembalikan pinjamannya dalam jangka waktu (tenor) yang telah ditentukan di akad. ${ }^{10}$

\section{Penetapan Harga Jual Pembiayaan Murabahah di BMT AL-Falah}

Berdasarkan Hasil wawancara dengan Ibu Ranti selaku bagian Accounting di BMT AL-Falah Sumber, mengenai penentuan margin

\footnotetext{
${ }^{10}$ Hasil Wawancara dengan Pak karmu selaku Senior marketing Terkait Prinsip Penilaian pembiayaan murabahah di BMT AL-Falah, pada hari kamis tanggal 23 maret 2017, pukul 10.00 .
}

keuntungan yang ada di BMT ALFalah Sumber, itu merupakan kebijakan yang telah ditentukan dari BMT Al-Falah Pusat. Pihak cabang hanya melaksanakan kebijakan yang ada. Jadi, angka-angka persentase margin keuntungan yang telah ditentukan pada plafon pembiayaan tertentu, seperti $1,8 \%$ flat per bulan untuk pembiayaan Rp 10.000.000,00Rp 300.000.000,00 hingga margin $2,5 \%$ flat per bulan untuk pembiayaan Rp $\quad 1.000 .0000-R p \quad 10.000 .000,00$ merupakan kebijakan dari BMT ALFalah Sumber.

Namun jika dianalisis lebih lanjut, penentuan angka-angka persentase tersebut tidak dilakukan secara sembarang. Margin keuntungan yang ditetapkan oleh BMT AL-Falah pusat pun mempertimbangkan referensi margin keuntungan, dimana BMT ALFalah juga melihat margin keuntungan yang ditetapkan oleh BMT lainnya sebagai kompetitor langsung terdekat. Selain itu BMT juga mempertimbangkan persaingan dengan tingkat suku bunga dari bank konvensional sebagai kompetitor tidak langsung. Kemudian BMT AL-Falah juga melihat PPAP (Penyisihan Piutang Aktiva Produktif) yaitu pembiayaan untuk risiko portofolio atau penghapusan aktiva produktif dalam mengatasi pembiayaan bermasalah, rata-rata pembiayaan yang keluar serta tentu saja margin keuntungan yang ditetapkan adalah dalam rangka mencapai target bagi hasil yang diharapkan dapat diberikan kepada dana pihak ketiga. ${ }^{11}$

\footnotetext{
${ }^{11}$ Hasil Wawancara dengan ibu Ratih selaku Accounting tekait penetapan harga jual pembiayaan murabahah di BMT AL-Falah, pada hari kamis tanggal 23 Maret 2017, pukul 13.30.
} 
Setelah memperoleh referensi margin keuntungan, bank melakukan penetapan harga jual. Harga jual adalah penjumlahan harga beli atau harga pokok atau harga perolehan bank dan margin keuntungan. ${ }^{12}$

1. Pengakuan angsuran harga jual

a. Angsuran harga jual terdiri dari angsuran harga beli atau harga pokok dan angsuran margin keuntungan. Pengakuan angsuraan dapat dihitung dengan menggunakan empat metode, yaitu metode margin keuntungan menurun (sliding), metode keuntungan rata-rata, margin keuntungan flat, margin keuntungan annuitas. ${ }^{13}$ Metode penetapan harga jual murabahah yang di terapkan BMT AL-Falah adalah metode keuntungan flat yang mana perhitungan margin keuntungan terhadap nilai harga pokok pembiayaan secara tetap dari satu periode ke periode lainnya.

Adapun perhitungan angsuran pokok dan marjin per bulan dengan metode flat sebagai berikut: ${ }^{14}$

$$
(\mathbf{P} \times \mathbf{m})+(\mathbf{P} / \mathbf{j})
$$

$\mathrm{P}$ : jumlah pembiayaan $m$ : Margin keuntungan per bulan $\mathrm{j}$ : Jangka waktu pembayaran

Penetapan margin murabahah di BMT AL-Falah dilakukan atas kesepakatan kedua pihak. Apabila kedua pihak telah

\footnotetext{
${ }^{12}$ Adiwarman Karim,.....,255.

${ }^{13}$ Adiwarman Karim,.....255-256.

${ }^{14}$ Hasil Wawancara dengan ibu Ratih selaku Accounting tekait penetapan harga jual pembiayaan murabahah di BMT AL-Falah, pada hari kamis tanggal 23 Maret 2017, pukul 13.30.
}

bersepakat maka terjadilah kesepakatan, jika kedua pihak tidak sepakat maka akad tersebut bisa diubah atau bahkan dibatalkan.

Persentase margin pada pembiayaan murabahah di BMT AL-Falah telah ditentukan berdasarkan tingkat plafon pembiayaan tersebut dengan standar margin minimal yang telah ditentukan sebelumnya pada rapat komite per bulan. Penetapan besaran margin dalam rapat komite sendiri memperhatikan dari pantauan tim marketing tentang kondisi mitra usaha BMT. Ketentuan margin yang diberikan pada calon anggota dengan jangka waktu pembayaran 1 s/d 12 bulan bulan ditetapkan margin murabahah sebesar $1,8 \%$ sampe $2,5 \%$ per bulan, untuk calon anggota dengan jangka waktu pembayaran $1 \quad \mathrm{~s} / \mathrm{d} \quad 2$ tahun ditetapkan margin murabahah sebesar 2,5\% per bulan. Di BMT AL-Falah persentase margin sebesar $1,8 \%$ untuk pembiayaan skala besar 10 juta-300 juta, tenor lama, dan biasanya diberlakukan untuk anggota yang sudah lama bergabung di BMT AL-Falah. Sedangkan persentase margin $2,5 \%$ biasanya untuk pembiayaan skala kecil 1 juta-10 juta, tenor jangka pendek, dan diperuntukan bagi calon anggota yang baru mengajukan pembiayaan di BMT AL-Falah. Besaran margin tidak akan berubah dan bersifat tetap. ${ }^{15}$

\footnotetext{
${ }^{15}$ Hasil Wawancara dengan ibu Ratih
} selaku bagian Accounting Margin keuntungan pembiayaan murabahah di BMT AL-Falah, pada hari kamis tanggal 23 Maret 2017, pukul 13.30 
$\begin{array}{lcr}\text { Penetapan } & \text { margin } & \text { biasanya } \\ \text { dilakukan } & \text { dengan } & \text { cara } \\ \text { melakukan } & \text { survey } & \text { anggota }\end{array}$ terlebih dahulu. Anggota yang mengajukan pembiayaan akan dianalisis kemampuan bayarnya yang dapat dilihat dari besarnya pendapatan yang dimiliki, selain dilihat dari pendapatan nasabah, penetapan margin juga memperhitungkan beban alokasi bagi hasil tabungan anggota yang dananya digunakan untuk pembiayaan (pihak ketiga), biaya operasional BMT, serta keuntungan BMT yang menjadi sisa hasil usaha yang nantinya akan dibagikan kepada anggota. Akan tetapi pada pelaksanaannya hal tersebut tidaklah selamanya mengikat, karena pada prakteknya penetapan margin dilakukan atas dasar kerelaaan dan kesepakatan bersama antara kedua pihak yang berakad.

Berdasarkan hasil wawancara dengan Ibu Runiah, diketahui bahwa Ibu Runiah adalah salah satu anggota BMT AL-Falah yang sudah cukup lama menjadi mitra BMT dan sudah sering mengajukan pembiayaan murabahah di BMT AL-Falah. Menurutnya, di BMT AL-Falah dalam menentukan margin atau mengambil keuntungan masih dibilang normal-normal saja tidak terlalu tinggi kalau dibandingkan dengan bank-bank umum seperti Bank BRI atau koperasi lainnya, BMT lebih murah, tidak berat juga untuk angsuran perbulannya. Kalau ada keterlambatan membayar angsuran tidak ada uang denda, berbeda dengan meminjam di bank yang kalau telat satu bulan tidak membayar angsuran, pasti ada uang dendanya. Adanya pembiayaan murabahah yang diberikan oleh BMT AL-Falah sangat membantu sekali terutama dalam memberikan modal untuk para pedagang dalam mengembangkan usahanya. Dan kali ini ibu runiah mengajukan pembiayaan murabahah untuk modal usaha jualan jajanan dengan mengajukan pembiayaan sebesar Rp 4.000.000, biaya yang dibebankan adalah sebesar Rp 23.000 dan margin keuntungan yang diberikan $2,5 \%$ per bulan dengan masa angsuran (tenor) 12 bulan. $^{16}$

Adapun metode perhitunganya adalah sebagai berikut:

Jenis pembiayaan: Murabahah

Harga beli : Rp.4.000.000

Biaya-biaya :

Biaya Adm. Rp $\quad 15.000$

Biaya Materai Rp $\quad 6.000$

Biaya Survey

Biaya Notaris

Biaya Asuransi jiwa Rp 2.667

Biaya Lain-lain

Total Biaya $\quad$ Rp 23.667

Jangka waktu pembayaran $(\mathrm{j})=1$ tahun (12 bulan)

Keuntungan jual beli

$=(P \mathrm{j}):(P \cdot \mathrm{m}) \mathrm{j}$

$=($ Rp. $4.000 .000 \times 2.5 \%) \times 12$ bulan

$=\operatorname{Rp} 100.000 \times 12$

$=\mathrm{Rp} 1.200 .000$

Harga Jual $(\mathrm{Hj})=\mathrm{P}+\mathrm{Pj}$

$=\operatorname{Rp} 4.000 .000+\operatorname{Rp} 1.200 .000$

$=\mathrm{Rp} .5 .200 .000$

Pengikatan: intern/ tetap

${ }^{16}$ Hasil Wawancara dengan ibu runiah anggota pembiayaan murabahah di BMT AL-Falah Sumber 
Cara Pengembalian: Angsuran per

bulan $=\mathrm{Hj} / \mathrm{j}$

$=\operatorname{Rp} 5.200 .000 / 12$

$=\operatorname{Rp} 433.333$

Secara terperinci sebagai berikut:

Skema Angsuran ibu Runiah

(Pemb.Murabahah)

\begin{tabular}{cccccc}
\hline Tanggal & $\begin{array}{c}\text { Sisa } \\
\text { Angsuran } \\
\text { (Rp) }\end{array}$ & Tag-Modal & Tag-Margin & $\begin{array}{c}\text { Total } \\
\text { Angsuran }\end{array}$ \\
\hline 22-Apr-17 & 5.200 .000 & 333.333 & 100.000 & 433.333 \\
\hline 22 Mei 17 & 4.766 .000 & 333.333 & 100.000 & 433.333 \\
\hline 22 Juni 17 & 4.333 .334 & 333.333 & 100.000 & 433.333 \\
\hline 22 Juli 17 & 3.900 .001 & 333.333 & 100.000 & 433.333 \\
\hline 22 Agust 17 & 3.466 .668 & 333.333 & 100.000 & 433.333 \\
\hline 22-Sep-17 & 3.033 .335 & 333.333 & 100.000 & 433.333 \\
\hline 22 Okt 17 & 2.600 .002 & 333.333 & 100.000 & 433.333 \\
\hline 22-Nov-17 & 2.166 .669 & 333.333 & 100.000 & 433.333 \\
\hline 22 Des 17 & 1.733 .336 & 333.333 & 100.000 & 433.333 \\
\hline 22 Jan 18 & 1.300 .003 & 333.333 & 100.000 & 433.333 \\
\hline 22 Feb 18 & 866.670 & 333.333 & 100.000 & 433.333 \\
\hline 22 Mar 18 & 433.337 & 333.337 & 100.000 & 433.337 \\
& Total & $\mathbf{4 . 0 0 0 . 0 0 0 . 0 0}$ & $\mathbf{1 . 2 0 0 . 0 0 0 . 0 0}$ & \\
\hline & & Sumber : Data primer diolah & \\
\hline
\end{tabular}

Jika dilihat dari penentuan harga jual beli murabahah tersebut, metode yang digunakan oleh BMT AL-Falah dalam menetapkan harga jual murabahah dapat dianalisis sebagai berikut:

1. Penetapan margin/keuntungan yang dilakukan oleh BMT Al-Falah menggunakan fixed rate dengan metode flat rate dimana penetapan margin dan hutang pokok yang dibebankan setiap bulan adalah sama sehingga pembayaran total cicilan setiap bulan besarnya tetap.

2. Penetapan harga jual murabahah pada BMT mempertimbangkan Al-Falah beban keuntungan yang harus diberikan kepada pemegang saham dan bagi hasil dana pihak ketiga. Hal ini karena operasional BMT Al-Falah lebih dominan bertumpu pada selisih keuntungan. Padahal besar atau kecilnya keuntungan, para anggota pembiayaan, menerima beban bagi hasil atas keuntungan anggota penyimpan dana dan pemilik saham yang seharusnya ditanggung oleh BMT baik dalam keadaan untung maupun rugi.

3. Penetapan margin yang dilakukan BMT AL-Falah masih tergantung pada kebutuhan untuk memperoleh keuntungan riil.

Dalam hal ini di BMT AL-Falah dalam hal penetapan harga jual murabahah sudah dikatakan sesuai dengan prinsip syariah, karena mengacu pada Fatwa DSN No. 04/DSN-MUI/IV/2000 tentang pembiayaan murabahah menyatakan bahwa bank ketika menjual barang kepada nasabah (pemesan) dengan harga jual senilai harga beli plus keuntungannya (margin) kemudian dalam hal ini Bank harus memberitahu secara jujur harga pokok barang kepada nasabah berikut biaya yang diperlukan. Nasabah membayar harga barang yang telah disepakati tersebut pada jangka waktu tertentu yang telah disepakati, di BMT AL-Falah dalam hal penetapan harga jual tidak terikat dengan suku bunga, penetapan harga jual dilakukan dengan prinsip saling ridho (Antaroddin), jujur, adanya proses negosiasi (tawar-menawar) antara BMT dan anggota serta kesepakatan antara kedua pihak tanpa unsur paksaan (ikroh).

Kesesuaian Penetapan Harga Jual Pembiayaan Murabahah di BMT AlFalah dengan Perspektif Syariah

Sebagaimana diketahui, pada dasarnya akad murabahah adalah jual beli dengan kesepakatan pemberian keuntungan bagi penjual dengan 
memperhatikan dan memperhitungkan modal awal si penjual. Unsur utama jual beli murabahah adalah adanya kesepakatan terhadap keuntungan. Keuntungan itu ditetapkan dan disepakati dengan memperhatikan modal si penjual. Keterbukaan dan kejujuran menjadi syarat utama terjadinya murabahah, sehingga yang menjadi karakteristik dari akad murabahah adalah penjual harus memberi tahu pembeli tentang harga pembelian barang dan menyatakan jumlah keuntungan yang ditambahkan pada harga beli barang tersebut. ${ }^{17}$

Jadi, pada dasarnya perhitungan margin (keuntungan) pembiayaan murabahah dengan menggunakan fixed rate dengan metode flat rate margin yang dilakukan BMT AL-Falah telah sesuai dengan tuntunan syariah karena sesuai dengan Fatwa DSN No. 04/DSN-MUI/IV/2000 tentang pembiayaan murabahah yang menyatakan bahwa bank ketika menjual barang kepada nasabah (pemesan) dengan harga jual senilai harga beli plus keuntungannya (margin) kemudian dalam hal ini bank harus memberitahu secara jujur harga pokok barang kepada nasabah berikut biaya yang diperlukan. Nasabah membayar harga barang yang telah disepakati tersebut pada jangka waktu tertentu yang telah disepakati. Penetapan harga jual di BMT AL-Falah juga dilakukan dengan melihat prinsipprinsip penetapan harga jual dalam Islam, yaitu saling ridha (antarrodin), tidak ada ada paksaan (ikroh), jujur, adil dan dilakukan negoisasi terlebih dahulu. $^{18}$ Dijelaskan dalam Al-Quran

17 Ibnu Rusyd, Bidayatul Mujtahid wa Nihayatul Mugtashid, Beirut : Lebanon : Dar alKutub Al-Ilmiyah, tt., h. 293.

18 Wawancara dengan Pak Azhar,ST selaku Manager Cabang Sumber Terkait Penerapan Produk pembiayaan murabahah di yang pertama, dilakukan dengan dasar suka sama suka tidak ada unsur paksaan (ikroh), sebagaimana firman Allah dalam surat An-Nisa ayat 29 yang artinya:

"Hai orang-orang yang beriman, janganlah kamu saling memakan harta sesamamu dengan jalan yang batil, kecuali dengan jalan perniagaan yang berlaku dengan suka sama-suka di antara kamu. dan janganlah kamu membunuh dirimu; Sesungguhnya Allah adalah Maha Penyayang kepadamu,"19

Prinsip kedua dalam penetapan harga setelah prinsip ar-ridha adalah prinsip keterbukaan. Pelaksanaan prinsip keterbukaan ini adalah transaksi yang dilakukan dituntut untuk berlaku benar dalam pengungkapan kehendak dan keadaan yang sesungguhnya, sehingga tidak ada pihak yang merasa dirugikan dalam ketetapan harga yang ada saat bertransaksi.

Ketiga adalah prinsip kejujuran, kejujuran merupakan pilar yang sangat penting dalam Islam, sebab kejujuran adalah nama lain dari kebenaran itu sendiri. Islam melarang kebohongan dan penipuan dalam bentuk apapun, sebab nilai kebenaran ini akan berdampak langsung kepada para pihak yang melakukan transaksi dalam perdagangan dan masyarakat secara luas. Prinsip ini berdasarkan pada QS. Al-Imran ayat 77 yang artinya:

"Sesungguhnya orang-orang yang menukar janji (nya dengan) Allah dan sumpah-sumpah mereka dengan harga yang sedikit, mereka itu tidak mendapat bahagian (pahala) di

BMT AL-Falah, pada hari Selasa tanggal 14 Februari 2017, pukul 10.00.

${ }^{19}$ H. Veithzal Rivai,Islamic Financial Management:Teori, Konsep, dan Aplikasi, (Jakarta PT RajaGrafindo,2008), 146. 
akhirat, dan Allah tidak akan berkatakata dengan mereka dan tidak akan melihat kepada mereka pada hari kiamat dan tidak (pula) akan mensucikan mereka. Bagi mereka azab yang pedih. ${ }^{20}$

Prinsip selanjutnya dalam penetapan harga setelah ketiga prinsip yang telah dipaparkan di atas adalah prinsip keadilan. Adil berasal dari bahasa Arab yang berarti berada di tengah-tengah, jujur, lurus, dan tulus. Secara terminologi, adil bermakna suatu sikap yang bebas dari diskriminasi dan ketidakjujuran. Dengan demikian orang yang adil adalah orang yang sesuai dengan standar hukum baik hukum agama, hukum positif (hukum negara), maupun hukum sosial (hukum adat) yang berlaku. $^{21}$ Jadi, dalam menetapkan harga pun harus bersikap adil sehingga tidak ada pihak yang didzhalimi. Islam mengharamkan kezaliman, sebagaimana firman Allah SWT dalam Q.S. Hud ayat 113 yang artinyai:

"Dan janganlah kamu cenderung kepada orang-orang yang zalim yang menyebabkan kamu disentuh api neraka, dan sekali-kali kamu tiada mempunyai seorang penolong pun selain daripada Allah, kemudian kamu tidak akan diberi pertolongan". ${ }^{22}$

Ayat-ayat diatas menjelaskan bahwasanya sebelum terjadinya kesepakatan antara calon anggota

20 Departemen Agama RI, Al-Qur'an dan terjemahnya. Al-Jumanatul, (Bandung : CV penerbit ART. 2012), 60

${ }^{21}$ Anto, Hendrie. Pengantar Ekonomika Mikro Islami. (Yogyakarta: Ekonisia,2003), 113

${ }^{22}$ Departemen Agama RI, Al-Qur'an dan terjemahnya. Al-Jumanatul, (Bandung : CV penerbit ART. 2012), 235. dengan BMT atas dasar negoisasi, dalam menentukan harga jual, terlebih dahulu di jelaskan kepada anggota besar harga belinya kemudian ditambah biaya yang dikeluarkan serta ditambah keuntungan yang akan diperoleh BMT. Sehingga terjadi kesepakatan harga yang selanjutnya dilakukan transaksi jual beli secara baik dan benar serta maslahat yang sesuai dengan ketentuan yang dibenarkan syariat Islam.

Mengenai berapa persen besaran keuntungan yang boleh diambil oleh para pedagang, di dalam Al-Quran tidak ditemukan satu dalilpun yang membatasi keuntungan yang boleh ditetapkan pedagang.

Bahkan sebaliknya, ditemukan beberapa dalil yang menunjukkan bahwa pedagang bebas menentukan persentase keuntungannya. ${ }^{23}$ Berikut adalah sebagian dari dalil-dalil tersebut. Pertama,

$$
\begin{aligned}
& \text { عَنْ عُرْوَةَأَنَّ النَّبِّيَّ صلى الله عليه وسلّمه، أَعْطَاهُ }
\end{aligned}
$$

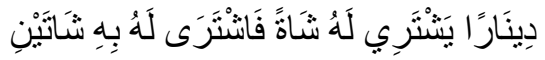

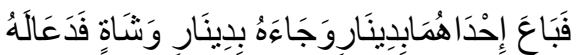

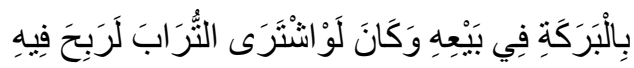

"Dari Urwah Al Bariqi, bahwasanya Rasulullah Shalallahu 'Alaihi wa Sallam memberinya satu dinar uang untuk membeli seekor kambing. Dengan uang satu dinar tersebut, dia membeli dua ekor kambing dan kemudian menjual kembali seekor kambing sebesar satu dinar. Selanjutnya dia datang menemui Nabi Shalallahu 'Alaihi wa Sallam dengan membawa seekor kambing dan uang satu dinar. Rasulullah Shalallahu

${ }^{23}$ Deliarnov, Perkembangan Pemikiran Ekonomi, (Jakarta: PT. RajaGavindo Persada, 2005), 44 
'Alaihi wa Sallam mendoakan keberkahan pada perniagaan sahabat Urwah, sehingga seandainya ia membeli debu, niscaya ia mendapatkan laba darinya. ${ }^{24}$ (HR. Bukhari, no. 3443)

Pada kisah ini, sahabat Urwah ra dengan modal satu dinar, ia mendapatkan untung satu dinar atau $100 \%$. Pengambilan untung sebesar $100 \%$ ini mendapat restu dari Nabi SAW. Bukan hanya merestui, bahkan Beliau berdo'a agar perniagaan sahabat Urwah senantiasa diberkahi. Sejak itu, Nabi Shalallahu 'Alaihi wa Sallam semakin lihai berniaga.

Kedua, berbagai dalil yang telah dikemukakan pada prinsip pertama juga bisa dijadikan dalil dalam masalah ini. Betapa tidak, pedagang telah secara sah memiliki barang dagangannya, maka tidak ada alasan untuk memaksanya agar menjual barangnya dengan harga yang tidak ia sukai.

Ketiga, Sahabat Rasulullah SAW, Anas bin Malik ra meriwayatkan bahwa para sahabat mengadu kepada Rasulullah SAW, "Wahai Rasulullah, telah terjadi kenaikan harga, hendaknya engkau membuat ketentuan harga jual." Menanggapi permintaan ini, Beliau bersabda, yang artinya: "Sesungguhnya Allah-lah yang menentukan pergerakan harga, Yang menyempitkan rezeki dan Yang melapangkannya. Sedangkan aku berharap untuk menghadap kepada Allah dan tidak seorangpun yang menuntutku dengan satu kezhaliman, baik dalam urusan jiwa (darah) atau harta kekayaan." (HR. Abu Dawud, no 3453, Tirmidzi, no. 1314 dan

24 Terjemahan kitab As-Sunah Edisi 07/THN.XIV/Dzulhijjah 1431H/November 2010 hal. 46-49. dinyatakan shahih oleh Syaikh Albani dalam kitab Misykatul Mashabih, No. 2894).

Dalam hadits lain Rasulullah SAW bersabda, yang artinya, "Janganlah engkau saling hasad, saling menaikkan penawaran barang (padahal tidak ingin membelinya), saling membenci, saling merencanakan kejelekan, saling melangkahi pembelian sebagian lainnya. Jadilah hamba-hamba Allah yang saling bersaudara. Seorang muslim adalah saudara muslim lainnya. Tidaklah ia menzhalimi saudaranya, tidak pula ia membiarkannya dianiaya orang lain dan tidak layak baginya untuk menghina saudaranya. (HR. Bukhari, no. 5717 dan Muslim, no. 2558).

Dalil-dalil tersebut menjelaskan bahwa Islam menghargai hak penjual dan pembeli untuk menentukan harga sekaligus melindungi hak keduanya. Dalam rangka melindungi hak penjual dan pembeli, Islam membolehkan bahkan mewajibkan pemerintah melakukan penetapan harag bila kenaikan harga disebabkan adanya penyimpangan antara permintaan dan penawaran.

Konsep harga yang adil telah dikenal oleh Rasullulah, yang kemudian banyak menjadi pembahasan dari para ulama di masa kemudian. Adanya suatu harga yang adil telah menjadi pegangan yang mendasar dalam transaksi yang Islami. Secara umum harga yang adil adalah harga yang tidak menimbulkan eksploitasi atau penindasan (kezaliman) sehingga merugikan salah satu pihak dan menguntungkan pihak yang lain. Penentuan harga dalam Islam ditentukan oleh kekuatan penawaran dan permintaan yang terjadi secara alami.

Berdasarkan uraian tersebut dapat dipahami bahwa diperbolehkan 
bagi siapapun untuk mencari keuntungan tanpa ada batasan keuntungan tertentu selama mematuhi hukum-hukum Islam, serta menentukan standar harga sesuai dengan kondisi pasar yang sehat. Namun bila terjadi penyimpangan dan kesewenangwenangan harga dengan merugikan pihak konsumen, tidak ada halangan bagi penguasa, sesuai dengan tugas dan tanggung jawabnya, untuk membatasi keuntungan pedagang atau menetapkan harga. Tindakan ini dilakukan harus melalui konsultasi dan musyawarah dengan pihak-pihak terkait agar tidak ada yang dilangkahi maupun dirugikan hak-haknya. ${ }^{25}$

Penentuan harga jual dan margin murabahah dianggap salah satu penyebab penyimpangan ajaran Islam. Bank-bank Islam beranggapan bahwa Al- Qur'an menghalalkan perdagangan, yaitu jual beli dengan laba, dan murabahah termasuk jual beli dengan laba. Mengingat tidak ada pembatasan dalam jumlah tertentu atas keuntungan yang diperoleh dari suatu perdagangan, maka bank-bank syariah secara bebas menentukan berapapun margin (keuntungan) dari kontrak murabahah. ${ }^{26}$

Wiroso dalam bukunya Jual Beli Murabaha mengatakan belum ditemukan dan belum ada rumus baku perhitungan keuntungan murabahah. Bank syariah ataupun BMT dalam menentukan keuntungan murabahah masih menggunakan pendekatan base

\footnotetext{
${ }^{25}$ K. Lubis, Suhrawardi. Hukum Ekonomi Islam. Jakarta: Sinar Grafika, 2000.

${ }^{26}$ Pembiayaan murabahah merupakan salah satu bentuk Natural Certainty Contract, yaitu kontrak dalam bisnis yang memberikan kepastian pembayaran, baik dari segi jumlah (amount) maupun waktu (timing). Selain murabahah, Ijarah juga termasuk dalam bentuk ini. Lihat Adiwarman Karim, Bank Islam Analisis Fiqh dan Keuangan, Jakarta : IIIT Indonesia, 2003, h. 51.
}

landing rate bank konvensional yang dinyatakan dalam bentuk persentase. Perhitungan keuntungan dengan cara sistem flat rate, dengan sistem annuitas yang dipergunakan oleh bank konvensional untuk menghitung bunga kreditnya saat ini merupakan teknik matematika dan teknik ini digunakan dalam menghitung keuntungan murabahah. $^{27}$

Namun demikian, menurut peneliti bukan hanya pada penentuan harga jual pada pembiayaan murabahah saja, tetapi juga produkproduk bank syariah lainnya harus tetap memperhatikan ketentuanketentuan yang dibenarkan menurut syariah. Oleh karena itu BMT perlu menetapkan metode yang tepat dan efisien agar produk murabahah dapat memberikan keuntungan secara adil baik BMT maupun anggota pembiayaan murabahah.

\section{PENUTUP}

Berdasarkan hasil penelitian penentuan harga jual pembiayaan murabahah di BMT AL-Falah Sumber, dapat disimpulkan bahwa mekanisme penetapan harga jual pembiayaan murabahah di BMT AL-Falah mempertimbangkan beberapa hal seperti, jangka waktu (tenor), penggunaan dana, dan kondisi anggotanya. Adapun untuk menganalisis kelayakan pembiayaan murabahah, BMT AL-Falah menggunakan prinsip 5C.

Penetapan harga jual pada akad murabahah di BMT AL-Falah menggunakan fixed rate dengan metode flate rate.

Menurut tinjauan hukum perspektif Islam, penetapan harga jual di BMT Al-Falah Sumber telah sesuai dengan tuntunan syariah, karena mengacu pada

\footnotetext{
${ }^{27}$ Wiroso,..., 78.
} 
Fatwa DSN No. 04/DSN-MUI/IV/2000 tentang pembiayaan murabahah. BMT Al-Falah juga dalam penetapan harga jual mempertimbangkan prinsip-prinsip Islam yaitu prinsip suka sama suka tidak ada paksaan (ikroh), saling ridha (antarrodin), prinsip kejujuran, dan prinsip keadilan.

\section{DAFTAR PUSTAKA}

Antonio, Muhammad Syafi'I, 2009,Islamic Banking Bank Syariah: Dari Teori ke Praktik). Jakarta: Gema Insani,

Arikunto,Suharsin, 2006.,Prosedur Penelitian Suatu Pendekatan Praktik Jakarta: Rieneka Cipta,

Aziz, Abdul Aziz dan Mariyah Ulfah,2010.,Kapita Selekta Ekonomi Islam Kontemporer, Bandung:Alfabeta,

Azwar,Saifuddin, 1998, Metode Penelitian. Yogyakarta : Pustaka Pelajar Offset,

Departemen Agama RI, Al-Qur'an dan terjemahnya. Al-Jumanatul, (Bandung : $\mathrm{CV}$ penerbit ART. 2012), 60

Departemen Agama RI,2012, AlQur'an dan terjemahnya. AlJumanatul, Bandung : CV penerbit ART,

Emzir,2012, Metodologi Penelitian Kualitatif Analisi Data, Jakarta : PT. Rajagrafindo Persada,

Euis Amalia,2009, Keadialan Distributif dalam Ekonomi Islam Penguatan Peran LKM dan UKM di Indonesia,Jakarta:Rajawai,

Hansen dan Mowen, 2001,Buku I Management Accounting Edisi 7. akarta :Salemba Empat,

Hendrie,Anto,2003,

Pengantar

Ekonomika Mikro Islami.

Yogyakarta: Ekonisia
Ibnu Rusyd, Bidayatul Mujtahid wa Nihayatul Mugtashid, Beirut : Lebanon : Dar al- Kutub AlIlmiyah,

Kusmiyati, Asmi Nur Siwi. 2007,Risiko Akad dalam Pembiayaan Murabahah pada BMT di Yogyakarta (dari Teori ke Terapan). Yogyakarta: La Riba.

Karim, Adiwarman ,2004, Bank Islam: Analisis Fiqh dan Keuangan, Edisi Kedua, Jakarta: Kharisma Putra Offset,

Lexy J Moleong,2013, Metodologi Penelitian Kualitatif, Bandung : PT. Remaja Rosdakarya,

Ma'sum, Mutiara Hadist Shahih Bukhari, Penerbit : Al-Basith

Muhammad.2009,Lembaga Keuangan Mikro Syariah. Yogyakarta: Graha Ilmu,

Mulyadi, 2001,Sistem Akuntansi, Yogyakarta : STIE YKPN,

Mulyana,Deddy, 2013, Metodologi Penelitian Kualitatif. Bandung: PT. Remaja Rosdakarya,

Nawawi, Ismail. 2012, Fikih Muamalah Klasik dan Kontemporer, Bogor: Penerbit Ghalia Indonesia,

Rivai, H.Veithzal , 2008,Islamic Financial Management:Teori, Konsep, dan Aplikasi, Jakarta PT RajaGrafindo,

Saeed, Abdullah. 2004, Menyoal Bank Syariah: Kritik atas Interpretasi Bunga Bank Kaum Neo-Revivalis, terj. Arif Maftuhin Jakarta: Paramadina,

Sudarsono, Heri, 2004,Bank dan Lembaga Keuangan Syariah, cet ke-2 Yogyakarta: Ekonesia,

Suhendi, Hendi DKK, 2004, BMT dan Bank Islam, Bandung: Pustaka Bani Quraisy,

Soedrajat, Setyo. 2004, Manajemen Pemasaran Jasa Bank, Cet. 
Pertama, Jakarta:PT. Ikral Mandiri Abadi,

Sutan,Remi Sjahdeini. 2014, Perbankan Syariah, Produkproduk dan aspek-aspek hukumnya. Jakarta:Kencana Prenadamedia Group

Wiroso,2005,Jual Beli Murabahah, Yogyakarta:UII Press 